\title{
RESEARCH INTO MECHANICAL PROPERTIES OF MINCED MEAT AND FINISHED PRODUCTS
}

\author{
Yuriy Suchenko \\ Department of Processing of agricultural production \\ «National University Life and Environmental Sciences of Ukraine» \\ 15 Geroev Oborony str., Kyiv, Ukraine, 03041 \\ suhenko@ukr.net \\ Vladislav Suchenko \\ Department of standardization and certification of agricultural products \\ «National University Life and Environmental Sciences of Ukraine» \\ 15 Geroev Oborony str., Kyiv, Ukraine, 03041 \\ standardization@ukr.net
}

Mikhail Mushtruk

Department of processes and equipment for Processing of agricultural production «National University Life and Environmental Sciences of Ukraine»

15 Geroev Oborony str., Kyiv, Ukraine, 03041

mixej.1984@ukr.net

Vladimir Vasyliv

Department of processes and equipment for Processing of agricultural production «National University Life and Environmental Sciences of Ukraine»

15 Geroev Oborony str., Kyiv, Ukraine, 03041

vasiliv-vp@ukr.net

Yuriy Boyko

Departments of machine building certification and standardization of equipment «National University of Food Technologies»

68 Vladimirskaya str., Kyiv, Ukraine, 01601

boykoyi@ukr.net

\begin{abstract}
Studies were conducted of the stressed-strained state of biopolymers of meat, which were exposed to the processes of elastic, residual and highly elastic deformation at cutting and mincing. Analysis of the structure of this natural biopolymer and the evaluation of mechanical characteristics of meat under normal and low temperatures are important factors that are taken into account for the rational selection of meat mincing machines and tools in the production of meat products, minced meat, semi-finished and sausage products.

The structure of meat is a system of structured protein fibers, impregnated with tissue fluid, which is protein sol that contains organic and inorganic substances, soluble in it. The tissues that the meat is composed of belong to natural biopolymers, so conducting analytical studies into mechanical properties of meat within the framework of our understanding of the mechanics of polymers will make it possible to improve mincing processes, employed during manufacturing of meat products.

In order to prevent meat overheating, the mincing process is performed at several stages. For example, in cutting mechanisms of choppers, they use a row of knives and grids with holes, diameter of which gradually changes from the original size of $0.06 \mathrm{~m}$ to $0.003-0.002 \mathrm{~m}$ in the outlet grids. Quality indicators of the finished products are affected by mechanical characteristics of raw materials and the way the cutting process is carried out.

In the course of conducted analysis it was found that in modern food production there remain unresolved important problems, which address current issues, related to rheological and structural mechanical properties of meat raw material. First of all, it concerns theoretical and practical developments that enhance an understanding of physico-chemical and mechanical properties of raw materials, which will make it possible to develop theoretical foundations and experimentally substantiate the new conceptual approach to solving the task of improving the quality of semi-finished products and durability of equipment at meat processing enterprises of APC. The research is the basis for constructive and technological solutions, choice of mode, kinematic and dynamic parameters of
\end{abstract}


cutting devices, steel and wear resistant coatings for cutting tools that provide saving of energy and materials at meat mincing, high quality of minced meat. and finished products and appropriate service life of the equipment.

It was established that in order to determine characteristics of the strained state of meat, it is necessary to apply a circular diagram of loading-unloading, which allows analysis of behavior of the sample in a closed cycle of changing in external load. An analysis indicates a very large dependence of meat elasticity module on temperature. Dependences of this kind are generally characteristic of polymer bodies.

Keywords: natural biopolymer, meat-processing tools, rheological parameters of raw materials, mechanical properties of meat, deformation process, intermolecular distances of fibers, energy parameters of cutting.

\section{Introduction}

The structure of meat is a system of structured protein fibers, impregnated by tissue fluid, which is protein sol that contains organic and inorganic substances, soluble in it. The tissues that meat is composed of belong to natural biopolymers, so conducting analytical studies of mechanical properties of meat as a part of mechanics of polymers will enable us to improve mincing processes, used in the course of manufacturing of meat products. Fundamental research into processes of meat deformation under load were carried out by different researchers [1-9]. However, results of research contain a number of contradictions, for example, up to now, there is no scientifically substantiated approach to the construction of mathematical models of technological processes that would sufficiently consider structural-mechanical characteristics (SMC) of a product, which leads to numerous errors in calculations that make it impossible to perform physical and mathematical modelling of meat mincing processes [10-13].

The goal of present work is to evaluate analytically influence of the stressed-strained state of meat raw materials with the aim of subsequent development of methods of mathematical description of deformation properties of meat under the influence of technological loads at mincing, which significantly affect energy parameters of cutting, durability and reliability of meat mincing machines, and quality of meat products and semi-finished products.

Procedure of research is based on the analytical generalization of knowledge on anatomy of animals, laws of continuum mechanics, comparative evaluation of properties of high-molecular natural compounds of synthetic polymers and is the basis for providing sustainable design of meat processing tools and machines.

\section{Materials amd methods}

The objects of experiments were "model" minced meat, which comprised different percentage of beef, pork and salted fat (1.50\% of beef and $50 \%$ of pork; $2.50 \%$ of beef, $30 \%$ of pork and $20 \%$ of salted fat; $3.30 \%$ of beef, $50 \%$ of pork and $20 \%$ of salted fat). We also explored production compositions of minced meat for the different kinds of sausage products: Rosiiski sausages, beef and pork sausages, Doctor sausage, which contain different amount of beef, pork and fat in their formulations.

In the experiments, we mainly used meat, preliminarily minced on choppers with grids of different diameters. At the beginning of mincing, beef with the addition of water and ice of approximately $50 \%$ of the estimated norm (500 grams of beef, $50 \mathrm{ml}$ of water and 25 grams of ice) was loaded into the cutter and minced for $0.5-1 \mathrm{~min}$ because the maximum amount of proteins from minced beef meat transfer from cellular structures to continuous phase $3 \mathrm{~min}$. earlier than it does from multi-component meat. Then $50 \%$ of pork $(500 \mathrm{~g})$, spices $(2.5 \%$ salt by weight of meat $)$, the rest of the water and ice (50 $\mathrm{ml}$ of water and 25 grams of ice) were added. After obtaining homogeneous system in the process of mincing, samples of beef were taken for determining its SMC (structural-mechanical characteristics).

Chemical composition of raw materials, RP (rheological properties) and SMC of meat products were determined by standard methods [14-18]. For each sample, we determined amount of moisture $\mathrm{W}$, protein $\mathrm{B}$, fat $\varphi$, ash and moisture content $\mathrm{U}$ (moisture content in $1 \mathrm{~kg}$ of completely drysubstance, which includes ash). 
From rheological characteristics, the most sensitive to changes in chemical composition of minced raw materials - boundary shear strain (BSS), was selected. Static BSS $\left(\theta_{0}\right)$ was defined on penetrometer PMDP and dynamic BSS $\left(\theta_{\text {un }}\right)$ - on MRP-4 m (State Standard 50814-95). Viscosity, stickiness, moisture binding ability of minced meat were determined according to recommendations [19-23].

Mass fraction of protein in meat products was determined according to State Standard 25011 and State Standard 30453 using devices Kjeltec 2460 and Kjeltec System 1002 of company "Gekator" (Sweden). Fat content was determined by DSTU 4436:2005.

\section{1. Experiments}

Fig. 1 shows a general view and schematic of the plant, the structure of which was borrowed from the National University of Food Technologies, Kyiv, which was upgraded and used for the potentiostatic studies of corrosion-mechanical wear (CMW). A scheme of face friction was used, when sample 1 rotated relative to stationary cylindrical sample 2, pressed to it with load P.

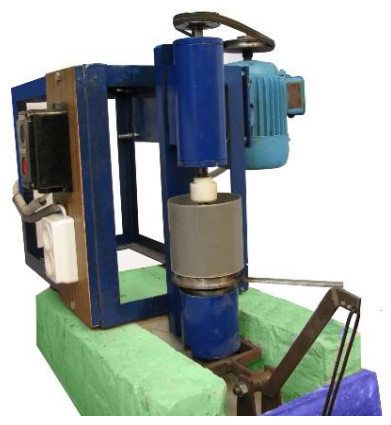

$a$

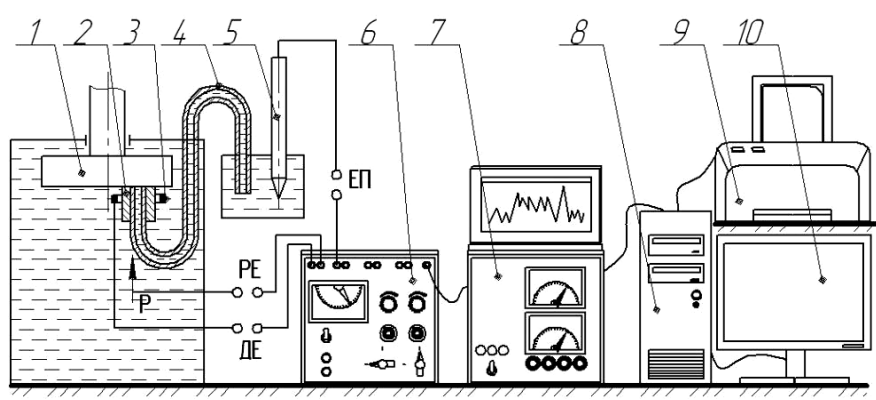

b

Fig. 1. General view $(a)$ and schematic $(b)$ of the plant to study the process of friction of metals in electroconductive food media by potentiostatic method

Polarization of the system and electrochemical measurement were carried out using electrochemical cells, which are a three-electrode system. It consisted of the studied (operating) electrode $(\mathrm{OE})$ - sample 2 (or 1), reference electrode (RE) (chlorsilver), in relation to which $\varphi$ was measured, and additional platinum electrode 3 (AE), which formed a polarization chain with AE. $\varphi$ was measured and polarization curves were taken using the storage tube 6 of make P-5827 M, connected with the electronic adapter 7, the system computer unit 8 , the plotter 9 and the monitor 10. The system is equipped with a dynamometer for measuring the moment of friction (not shown in the Fig. 1).

If we put a sanding disc instead of the upper metal sample, a widely known method of metal surface stripping under solution will be implemented. Using it, stripping potential $\varphi_{Z}$ was measured. Comparison of $\varphi_{Z}$ and friction potential $\varphi_{T R}$ characterizes behavior of films, formed on friction surfaces. Potentials of surfaces are as important characteristic at evaluation of mechanical properties of metals as hardness or strength boundary. 
As a result of the conducted studies, it was found that polarization of frictional contact affects processes of evolution of dislocation structure of friction surfaces of materials in meat media and may be used to control energy-strength characteristics of the processes of their wear.

Regardless of the magnitude of $\mathrm{pH}$, corrosion-active media (CAM) of the industry contribute to localization of deformation at thinner surface layers of details compared with lubrication-free friction. That is why many details of technological meat mincing equipment are exposed to considerable wear. In some cases, its intensity is so great that service life of some of parts in not more than a few days, for example, knives and meat mincing choppers, cutters and other mincers.

Films of secondary structures, barrier and sorbed layers on metals, which in most cases, crucially influence the character of deformation and destruction of friction surfaces of corresponding parts and cutting tools, have semiconductor properties, besides, many oxides have the GCK structure, like silicon and lithium fluoride crystals that were used in the research. To create stressed state, samples of monocrystals were gripped in the clamp before the experiment. In this state, monocrystals were deformed with the indentor on a microtribometer, the design of which was proposed by M. A. Sologub and O. Y. Novytsky (NUFT).

The experiments were conducted at lubrication-free friction of the indentor of the sample, in distilled water ( $\mathrm{pH}$ 7.0), which is the basis of chemical composition of meat, as well as in meat juice, pressed out of one sample of muscular tissue of milk veal of the $2^{\text {nd }}$ grade 2 hours after slaughtering ( $\mathrm{pH} 7.4$ ) and after 240 hours (after full completion of autolysis at temperature of $0{ }^{\circ} \mathrm{C}(\mathrm{pH} 5.5)$. Chemical composition of meat and the acid-alkaline balance $(\mathrm{pH})$ of meat juice was determined in the Ukrainian laboratory of quality and product safety of agricultural production National University of Life and Environmental Sciences (NULES) of Ukraine.

Using a microtribometer, we studied the influence of properties of meat juice, nature and structure of monocrystalline and polycrystalline materials, their flat and volume-strained state on mechanical-physical and electrochemical processes at friction of sliding, as well as on the dislocational structure of the deformed area. The influence of CAM on development of elastic-plastic deformations in steels at friction of sliding was determined by the photoelasticity method on the samples of annealed steel $65 \mathrm{G}$, which is most often used for the manufacture of meat cutting tools.

Experience of operation of meat cutting tools shows that it is alloyed steel tools that are of limited use in the industry, although due to a number of their physical and mechanical properties they would have to get more widespread use. Totally, this leads to a dramatic decrease in the efficiency of minicing and makes achieving a high level of product quality problematic. To assess force interaction of cutting bodies of machines with meat products, there were used a number of plants and devices to measure cutting efforts under static, dynamic and combined modes of cutting, as well as plants for evaluation of friction forces and meat deformation in the process of cutting, the vast majority of which was built by the author with assistance and under the guidance of Professor M. M. Klimenko in the period of joint work at the Department of Meat, Fish and Seafood of (NULES) of Ukraine.

It is best to study mechanical properties of meat during testing them for breaking. Performing some measurements of deformations based on the sample using sensors for such bodies as meat causes great technical difficulties due to its very low rigidity. Therefore, we applied the method based on testing the samples in the form of a round thin membrane that is loaded at uniform pressure.

In the course of experiment, we measured pressure $\mathrm{P}$ and the largest membrane deflection $\mathrm{W}$, corresponding to this pressure. By geometrical ratios, coordinates of the deformation diagram $\sigma-\varepsilon$ were established.

Low durability and effectiveness of meat mincing equipment, in particular cutting tools, is related, first of all, to inappropriate selection of materials and strengthening processing in the manufacture of parts, specific of their uncontrolled interaction with technological environment of the industry, which includes a complex set of mechanical, physical and electrochemical processes that affect the dislocation structure, electrode potentials, energy state of wearing of non-regulated surfaces, leading to a decrease in its performance and energy efficiency, decrease in SMC and quality of minced meat and finished products as well as significant losses for restoring workability of machines. 


\section{Result}

We studied relationships between the process of mincing of raw materials of different origin and chemical composition and rheological indicators and quality of forcemeats. and finished products.

Accepting as mean values the fat content equal to $1.4 \%(0.8 \div 2.0)$, protein content equal to $19.24 \%(19.0 \div 19.5)$ and ash content equal to $3.6 \%(3.4 \div 3.8)$ in beef of higher grade, we will consider changing of static $\theta_{0}$ and dynamic $\theta_{\text {un }}$ BSS of minced meat, minced in the choppers K6-FVZP-200 with the diameter of holes in the grid of $3 \mathrm{~mm}$, depending on humidity. The same parameters will be considered for beaf of $1^{\text {st }}$ grade and for lean pork (Fig. 2, a).
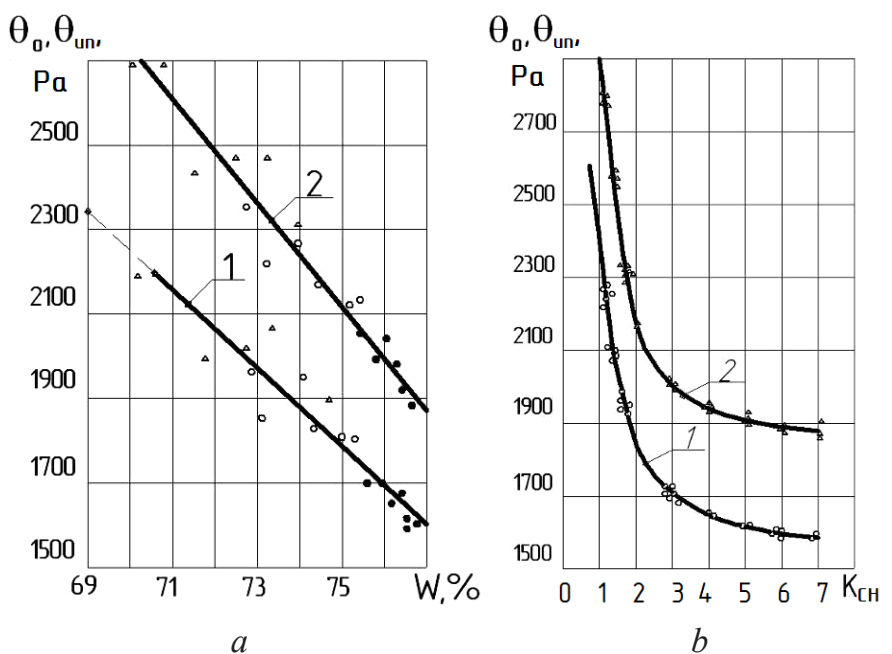

Fig. 2. Dependences of static $\theta_{0}$ (1) and dynamic $\theta_{\text {un }}$ (2) boundary shear stress of minced meat, minced in choppers with diameter of holes in grid lattice $\mathrm{d}_{\text {hole }}=3 \mathrm{~mm}$ on its humidity $\mathrm{W}(a)$ and

criterion of chemical composition $\mathrm{K}_{\mathrm{KH}}(b)$ : • - beef of top grade; o - beef of $1^{\text {st }}$ grade;

$$
\Delta \text { - lean pork }
$$

Obvious relationships between BSS and humidity of raw material, which does not depend on its type and grade and may be approximated by a straight line:

$$
\theta_{0} \text { or } \theta_{\mathrm{un}}=\mathrm{A}(1-\mathrm{a} \cdot \mathrm{W})
$$

where $\mathrm{A}$ and a are the empiric coefficients, $\mathrm{W}$ is the humidity of raw material in shares of units.

The magnitude of BSS is equal to zero at $\mathrm{a} \cdot \mathrm{W}_{\mathrm{CR}}=1$, where a is the coefficient, which indirectly characterizes the rate of decrease in magnitude of BSS depending on an increase in humidity, in this case, $\mathrm{W}_{\mathrm{CR}}$ is the true value of the rate of change, equal to tangent of slope angle of the straight line (1).

For static BSS: $A=9500$; $a=1.08$; for dynamic BSS: $A=11800$; $a=1.1$, then:

$$
\theta_{\mathrm{o}}=9150(1-1,08 \cdot \mathrm{W}), \quad \mathrm{W}_{\mathrm{CR}}=0,926 ; \theta_{\mathrm{un}}=11800(1-1,1 \cdot \mathrm{W}), \quad \mathrm{W}_{\mathrm{CR}}=0,926 .
$$

Structural-mechanical characteristics of raw materials depend on chemical composition, in particular on the content of protein, fat, and moisture. In order to comprehensively consider chemical composition of meat raw material, we will use criterion of chemical composition, proposed by S. V. Siutkin:

$$
\mathrm{K}_{\mathrm{KH}}=\mathrm{B} / \phi \cdot \mathrm{U}
$$

where $\mathrm{B}$ and $\phi$ are the content of protein and fat, respectively, in $1 \mathrm{~kg}$ of raw material, share of units; $\mathrm{U}$ is the moisture content of raw material, share of units. 
Graphical dependence of change in static and dynamic BBS of raw materials on criterion of chemical structure $\mathrm{K}_{\mathrm{kh}}$ is presented in Fig. 2, $\boldsymbol{b}$.

Mathematical provessing of this dependence allowed obtaining the following equation:

$$
\theta_{0} \text { or } \theta_{\mathrm{un}}=\mathrm{A}\left(\mathrm{a}+\mathrm{K}_{\mathrm{KH}}^{-1}\right)
$$

where $\mathrm{A}$ and a are the empiric coefficients.

For static BSS: $\mathrm{A}=604, \mathrm{a}=2.5$; for dynamic BSS: $\mathrm{A}=750$; $\mathrm{a}=2,4$, then

$$
\theta_{\hat{\imath}}=604\left(2,5-\mathrm{K}_{\mathrm{KH}}^{-1}\right), \mathrm{Pa} ; \theta_{\mathrm{un}}=750\left(2,4-\mathrm{K}_{\mathrm{KH}}^{-1}\right), \mathrm{Pa} .
$$

Error in calculations by these dependences does not exceed $\pm 2.5 \%$.

Kinetics of changes in static and dynamic BSS of dispersed medium of minced meat for various types of sausage on duration of mincing is presented in (Fig. 3).
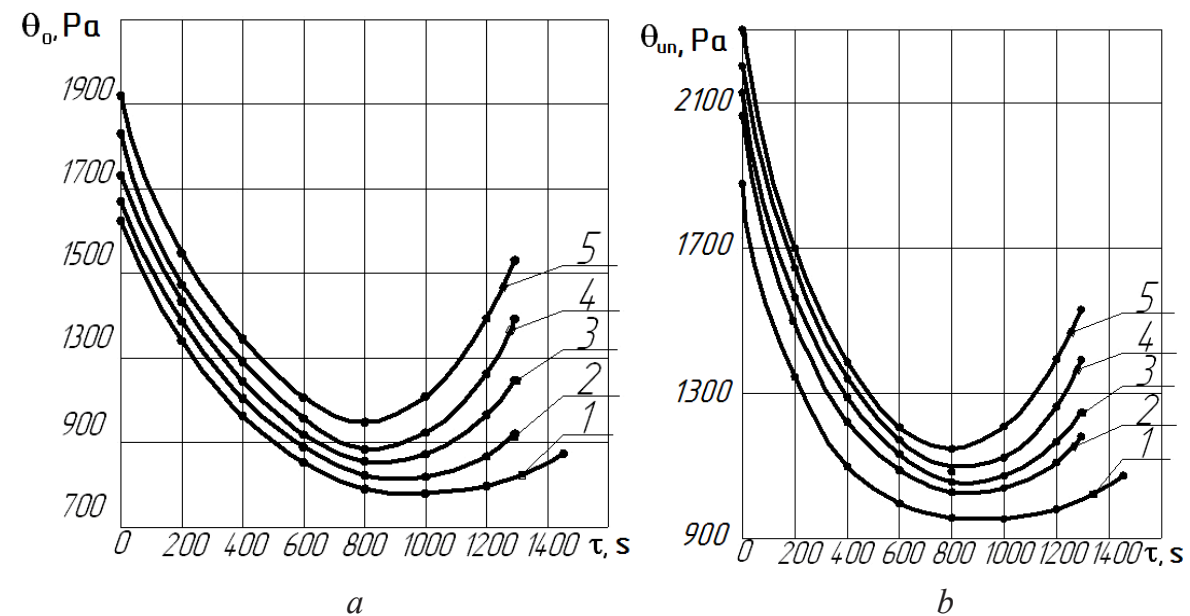

Fig. 3. Kinetics of changes in static $\theta_{0}(a)$ and dynamic $\theta_{\text {un }}(b)$ boundary shear stress on duration of mincing $\tau$ on cutter of dispersed medium for minced meat of uncooked smoked sausages: 1 - Fantasy; 2 - Moscow; 3 - Liubitelska, 4 - Radianska; 5 - Pork

Extreme point on the graphs characterizes the end of formation of primary structure with minimum moisture binding ability and corresponds to optimum values $\theta_{\mathrm{o}}^{\text {opt }}$ and $\theta_{\text {un }}^{\text {opt }}$, which determine the duration of meat mincing from raw materials of appropriate type, grade and chemical composition.

For analytic generalization of function $\theta_{0}=\mathrm{f}\left(\tau_{\mathrm{K}}\right)$, it is possible to propose equation:

$$
\theta_{0}=\mathrm{A}\left(1-\tau_{\mathrm{K}} / \tau_{\mathrm{K}}^{\mathrm{opt}}\right)^{2}+\theta_{0}^{\mathrm{opt}} ; \theta_{\mathrm{un}}=\mathrm{A}_{1}\left(1-\tau_{\mathrm{K}} / \tau_{\mathrm{K}}^{\mathrm{opt}}\right)^{2}+\theta_{\mathrm{un}}^{\mathrm{opt}},
$$

where $\theta_{0}, \theta_{\text {un }}$ are the values, respectively, of static and dynamic BBS of dispersed medium of minced meat of uncooked smoked sausages; $\mathrm{A}$ is the empirical coefficient that depends on formulation of the sausage; $\tau_{\mathrm{K}}$ is the assigned duration of mincing, $\mathrm{s}$; $\tau_{\mathrm{K}}^{\mathrm{opt}}$ is the optimum duration of mincing that corresponds to minimum value of $\mathrm{BSS}\left(\theta_{\mathrm{un}}^{\mathrm{opt}}, \mathrm{Pa}\right)$.

After processing the resulting experimental material mathematically, we obtained the following dependences:

$$
\begin{gathered}
\Theta_{\mathrm{o}}^{\mathrm{opt}}=720+300 / \mathrm{K}_{\mathrm{CH}}=300\left(2.4+\mathrm{K}_{\mathrm{CH}}^{-1}\right), \\
\Theta_{\mathrm{un}}^{\mathrm{opt}}=874+380 / \mathrm{K}_{\mathrm{CH}}=380\left(2.3+\mathrm{K}_{\mathrm{CH}}^{-1}\right), \\
\tau_{\mathrm{\kappa}}^{\mathrm{opt}}=640+96 \mathrm{~K}_{\mathrm{KH}}=640\left(1+0.15 \mathrm{~K}_{\mathrm{KH}}\right),
\end{gathered}
$$




$$
\begin{aligned}
& \mathrm{A}=767+350 / \mathrm{K}_{\mathrm{KH}}=350\left(2.19+\mathrm{K}_{\mathrm{KH}}^{-1}\right), \\
& \mathrm{A}_{1}=920+465 / \mathrm{K}_{\mathrm{KH}}=465\left(1.98+\mathrm{K}_{\mathrm{KH}}^{-1}\right) .
\end{aligned}
$$

By using these formulas, we optimized the process of getting minced meat for uncooked smoked sausages on a laboratory cutter.

Under production conditions, the process of fine mincing is greatly accelerated. Therefore, for further research, we selected an industrial cutter with bowl capacity of 2501 (SK), which provides for increased performance. The number of sickle-shaped knives was increased to 6 . Rotation frequency of the knives was $1325 \mathrm{~min}^{-1}$, rotation frequency of the bowl was $9.1 \mathrm{~min}^{-1}$. Results of the experiments are shown in Fig. 4.

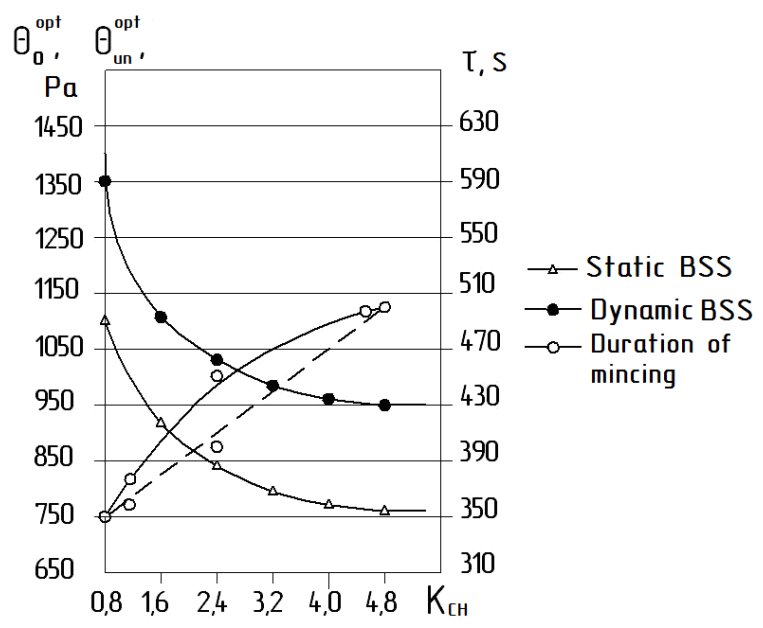

Fig. 4. Dependence of optimal values of static and dynamic BSS and duration of mincing on criterion of chemical composition of dispersed media of minced meat for uncooked smoked sausages (cutter SK)

We also studied mincing on big cutter (BC) with bowl capacity of 5001.

Mathematical processing of curves allowed obtaining the following dependences:

$$
\begin{gathered}
\Theta_{0}^{\mathrm{opt}}=300\left(2.4+\mathrm{K}_{\mathrm{KH}}^{-1}\right) ; \Theta_{\mathrm{un}}^{\mathrm{opt}}=375\left(2.3+\mathrm{K}_{\mathrm{KH}}^{-1}\right), \\
\tau_{\mathrm{K}}^{\mathrm{opt}}=325 \exp \left(0.1 \mathrm{~K}_{\mathrm{KH}}\right), \mathrm{s}, \text { or } \tau_{\mathrm{K}}^{\mathrm{opt}}=38.8\left(8.35+\mathrm{K}_{\mathrm{KH}}\right) .
\end{gathered}
$$

Obtained equations are similar to earlier obtained equations, describing meat mincing on the cutter of low performance, and differ only by coefficients.

Thus, optimal values of BSS of minced meat depend on its chemical composition and do not depend on performance of the used cutter. The optimal value of duration of meat mincing substantially depends on the type of the used cutter, its geometric and kinematic parameters.

Fine grinding of minced meat for boiled sausages provides formation of such particles, the surface of which, unlike minced meat for uncooked smoked sausages, binds maximum amount of moisture, forming a homogeneous mass with definite SMC. Duration of mincing varies and depends on kinematic characteristics of selected machines and structures of cutting nodes.

It was found out that the shear stress of finished product reaches the maximum value at the extreme duration of mincing. Meat crumpling work also depends on the duration of mincing, in this case, extreme magnitudes of this work for minced meat, obtained at different mincing machines, are the same. Changing the SMC of minced meat based on objective criteria of their evaluation, it is possible to achieve products of high quality. Complex of SMC is also necessary in order to predict the quality of new types of products. 
Performed experimental research and obtained mathematical dependences of processes that take into account properties of raw material and characteristics of equipment for mincing meat will make it possible: to identify the optimal duration of its processing on machines with different cutting capacity (generilized kinematic characteristic); identify relationship of change of strength (boundary shear stress), energy (work of shearing and bearing), compressive (relative volumetric deformation, modulus of elasticity, period of relaxation) and shear (boundary shear stress, plastic and effective viscosity) of characteristics of minced meat and finished products from raw materials with different criterion of chemical composition and a degree of mincing; to propose mathematical apparatus, to develop a procedure of calculation and to predict the quality of forcemeats and finished meat products and apply them for assigning controllable and managable modes of meat mince preparation, for designing of technological equipment, and development of new formulations.

\section{Conclusion}

The research conducted allows us to draw the following conclusions and recommendations:

1. Evaluation of behavior of meat in processes of its mincing may be partly based on the mathematical apparatus and methods of physical-chemical mechanics of chemical polymers. It is mathematically expedient to describe the diagrams of its deformation and other mechanical dependences with the use of mechanical or electric rheological models.

1. The optimal duration of meat mincing on different meat mincing machines depends on criterion of chemical composition of meat and generalized kinematic characteristics of machines. A degree of meat mincing directly influences its quality, duration of drying of uncooked smoked sausages and weight loss of boiled sausages at thermal processing, whereas controlled modes of minced meat preparation allow obtaining products with the assigned SMC.

3. We found interconnection of strength (boundary shear stress), energy (work of shearing and bearing), compressive (relative volumetric deformation, modulus of elasticity, period of relaxation) and shear (boundary shear stress, plastic and effective viscosity) characteristics of minced meat and finished products and a degree of mincing of raw material.

4. A mathematical apparatus is proposed that allows predicting quality (consistency) of the finished product by SMC of minced meat, which creates conditions for the development of a new range of meat products with predetermined properties and allows us to provide optimal term of crushing on machines with different cutting capacity.

\section{References}

[1] Sidoryak, A. N. (1996). Sovershenstvovanie protsessa izmelcheniya myasa. Moscow, 177.

[2] Alekseev, V. M., Bandurkin, N. G., Generalov, N. F. (1984). Oborudovanie dlya izmelcheniya myasa: Ekspress-informatsiya. TsNIITEImyasomolprom. Ser.: Myasnaya Promyshlennost. Zarubezhnyi opyt, 11.

[3] Sokolov, A. A., Pavlov, D. V., Bolshakov, A. S.; Sokolov, A. A. (1970). Tekhnologiya myasa i myasoproduktov. Moscow: Pishchevaya promyshlennost, 740.

[4] Wu, C., Yuan, C., Chen, S., Liu, D., Ye, X., Hu, Y. (2015). The effect of curdlan on the rheological properties of restructured ribbonfish (Trichiurus spp.) meat gel. Food Chemistry, 179, 222-231. doi: 10.1016/ j.foodchem.2015.01.125

[5] Shand, P. J., Ya, H., Pietrasik, Z., Wanasundara, P. K. J. P. D. (2007). Physicochemical and textural properties of heat-induced pea protein isolate gels. Food Chemistry, 102 (4), 1119-1130. doi: 10.1016/ j.foodchem.2006.06.060

[6] Lupi, F. R., Gabriele, D., Seta, L., Baldino, N., de Cindio, B. (2014). Rheological design of stabilized meat sauces for industrial uses. European Journal of Lipid Science and Technology, 116 (12), 1734-1744. doi: 10.1002/ejlt.201400286

[7] Zhang, F., Fang, L., Wang, C., Shi, L., Chang, T., Yang, H., Cui, M. (2013). Effects of starches on the textural, rheological, and color properties of surimi-beef gels with microbial tranglutaminase. Meat Science, 93 (3), 533-537. doi: 10.1016/j.meatsci.2012.11.013

[8] Damez, J.-L., Clerjon, S. (2013). Quantifying and predicting meat and meat products quality attributes using electromagnetic waves: An overview. Meat Science, 95 (4), 879-896. doi: 10.1016/j.meatsci.2013.04.037 
[9] Benavides, S., Villalobos-Carvajal, R., Reyes, J. E. (2012). Physical, mechanical and antibacterial properties of alginate film: Effect of the crosslinking degree and oregano essential oil concentration. Journal of Food Engineering, 110 (2), 232-239. doi: 10.1016/j.jfoodeng.2011.05.023

[10] Adams, S. A., Rhee, K. S. (1994). Improvement of shelf-life and sensory properties of precooked low-fat ground beef patties. Paper no. 47D-17. Annual meeting of the institute of food technologists. Atlanta.

[11] Cutter, C. N. (2000). Antimicrobial Effect of Herb Extracts against Escherichia coli O157:H7, Listeria monocytogenes, and Salmonella Typhimurium Associated with Beef. Journal of Food Protection, 63 (5), 601-607. doi: 10.4315/0362-028x-63.5.601

[12] Nychas, G. J. E., Drosinos, E., Board, R. G.; Board, R. G., Davies, A. R. (Eds.) (2009). Chemical changes in stored meat. Microbiology of Meat and Poultry. London: Blackie Academic and Professional, 288-326.

[13] Jin, T., Liu, L., Sommers, C. H., Boyd, G., Zhang, H. (2009). Radiation Sensitization and Postirradiation Proliferation of Listeria monocytogenes on Ready-to-Eat Deli Meat in the Presence of Pectin-Nisin Films. Journal of Food Protection, 72 (3), 644-649. doi: 10.4315/0362-028x-72.3.644

[14] Chan, J. T. Y., Omana, D. A., Betti, M. (2011). Functional and rheological properties of proteins in frozen turkey breast meat with different ultimate pH. Poultry Science, 90 (5), 1112-1123. doi: 10.3382/ ps.2010-01185

[15] Sokolov, A. A. (1965). Fiziko-khimicheskie i biokhimicheskie osnovy tekhnologii myasoproduktov. Moscow: Pishchevaya promyshlennost, 511.

[16] Tinyakov, G. G. (1967). Gistologiya myasopromyshlennykh zhivotnykh. Moscow: Pishchevaya promyshlennost, 416.

[17] Aleksander, R. (1999). Biomekhanika. Moscow: MIR, 340.

[18] Neyberg, G. (1961). Teoriya kontsentratsii napryazheniy v prizmaticheskikh sterzhnyakh, rabotayushchikh v usloviyakh sdviga, dlya lyubogo nelineynogo zakona, svyazyvayushchego napryazheniya i deformatsii. Mekhanika, 4, 117-130.

[19] Kuleshev, B. V. (1979). Issledovanie impulsnogo rezaniya i strukturno-mekhanicheskikh svoystv kostnoy tkani s tselyu razrabotki sootvetstvuyushchego oborudovaniya. Moscow, 194.

[20] Khlebnikov, V. V., Makhonina, V. A., Simonenko, A. S. (1975). Zavisimost rastvorimosti belkov i reologicheskikh svoystv farsha ot prodolzhitelnosti kutterovaniya. Myasnaya Industriya SSSR, 3, 33-35.

[21] Zabalueva, Y. Y., Pavlova, S. N., Leskova, S. Y. (2007). Metody issledovaniya myasa i myasnykh produktov. Ulan-Ude: Izd-vo VSGTU, 78.

[22] Nikolaev, B. A., Baranov, A. F. (1976). Issledovanie strukturno-mekhanicheskikh svoystv myasa metodom rastyazheniya. Myasnaya industriya SSSR, 6, 35-37.

[23] Kulmanova, N. (2000). Mekhanicheskie svoystva govyazhego myasa pri zamorazhivanii. Myasnaya industriya, 1, 17-21. 